\title{
Distribution of Lipid Compounds in Sediments from Conceição Lagoon, Santa Catarina Island, Brazil
}

\author{
Cesar A. Silva, Cristiane R. Oliveira, Inês R. W. Z. Oliveira and Luiz A. S. Madureira*
}

Departamento de Química, Universidade Federal de Santa Catarina, 88040-900 Florianópolis-SC, Brazil

\begin{abstract}
Compostos orgânicos provenientes de cinco amostras de sedimentos e um perfil com $75 \mathrm{~cm}$ foram coletados na Lagoa da Conceição, localizada na Ilha de Santa Catarina, com o objetivo de avaliar fontes de matéria orgânica. Os resultados que foram baseados na relação C:N:P, abundância relativa dos esteróis (com predomínio dos $\mathrm{C}_{27}$ ), álcoois $\left(0,2-1,2 \mu \mathrm{g} \mathrm{g}^{-1}\right)$ e hidrocarbonetos lineares $\left(0,4-5,0 \mu \mathrm{g} \mathrm{g}^{-1}\right)$, e no uso do Índice Preferencial de Carbono (CPI), indicaram que a matéria orgânica é preferencialmente de origem terrestre $(\mathrm{C} / \mathrm{N}>10$ e $\mathrm{CPI}>2)$. Em todos os locais observaram-se correlações significativas entre as quantidades de fósforo (TP, média 5,20 $\mu \mathrm{mol} \mathrm{g}^{-1}$ ) e carbono orgânico total (TOC, média $2,90 \mathrm{mmol} \mathrm{g}^{-1}$ ) com as frações de silte e argila. No perfil, que foi cronologicamente datado com o radionuclídeo ${ }^{210} \mathrm{~Pb}$, o intervalo de 55 a $75 \mathrm{~cm}$ apresentou predomínio de areia (>50\%). Entretanto, outros parâmetros, tais como TOC, TP e hidrocarbonetos também aumentaram nesse intervalo, o que sugere uma mudança na fonte de matéria orgânica.
\end{abstract}

Lipid compounds from five sediment-water interface samples and a sediment core with $75 \mathrm{~cm}$ depth were used to assess sources of organic matter in Conceição Lagoon, located on Santa Catarina Island. The results which were based on the molar $\mathrm{C}: \mathrm{N}: \mathrm{P}$ ratios, relative abundance of sterols (dominated by the $\mathrm{C}_{27}$ sterols), $n$-alkanols $\left(0.2-1.2 \mu \mathrm{g} \mathrm{g}^{-1}\right), n$-alkanes $\left(0.4-5.0 \mu \mathrm{g} \mathrm{g}^{-1}\right)$ and the Carbon Preference Index (CPI), indicated that the organic matter is predominantly of terrestrial origin $\left(\mathrm{C} / \mathrm{N}>10\right.$ and $\mathrm{CPI}>2$ ). Total phosphorus (TP, average $5.20 \mu \mathrm{mol} \mathrm{g}^{-1}$ ) and organic carbon (TOC, average $2.90 \mathrm{mmol} \mathrm{g}^{-1}$ ) contents were well correlated with the silt and clay fractions at all locations. In the sediment core, chronologically dated with the radionuclide ${ }^{210} \mathrm{~Pb}$, the depth interval from 55 to $75 \mathrm{~cm}$ was dominated by the sand fraction (> 50\%). However, parameters such as TOC, TP and $n$-alkane contents increased considerably at this depth suggesting a change in organic matter input sources.

Keywords: sediments, hydrocarbons, Conceição Lagoon, chromatography

\section{Introduction}

Lipid compounds constitute a minor but important fraction of the total organic matter in aquatic sediments. Sources of lipids include primary production, inputs of terrestrial material from the watershed region and products associated with microbial activity in the water and sediment. ${ }^{1,2}$ Of particular relevance to sediments of estuaries and lagoons are organic compounds such as ketones, sterols, fatty acids, hydroxy acids, $n$-alkanes and $n$-alkanols. ${ }^{3,4}$ These preserved components are also known as geolipids or biomarkers, because they can be linked with biological precursor compounds. Although organic compounds are subject to extensive biochemical

*e-mail: madureira@qmc.ufsc.br processes that may significantly alter their molecular structures and distributions, some of them can be used to reconstruct the history of organic matter production, inputs and preservation in lagoons. However, it is well known that to correlate them with specific living organisms is difficult and other biogenic parameters (e.g. C, N, and P) may be used for assessment of specific sources. ${ }^{5,6}$ Apart from natural contributions, lagoons are susceptible to inputs of pollutants from diffusive sources, mainly untreated sewage discharges and petroleum-related compounds.

Several reports have emphasized the great importance of Conceição Lagoon as a tourist resort and a fishing resource for the local people. ${ }^{7,8}$ Our study provides background information dealing with biogenic parameters such as total organic carbon (TOC), nitrogen (N) and phosphorus (total, TP; organic, OP; and inorganic, IP) and the nature and 
concentration of organic compounds distributed along the sediment-water interface. Linear hydrocarbons, alcohols ( $n$-alkanes and $n$-alkanols) and sterols are the classes of compounds that will be addressed here. Temporal changes in $n$-alkane distribution and nutrient inputs, reflected in the sedimentary record of TOC, $\mathrm{N}$ and $\mathrm{P}$ were evaluated using ${ }^{210} \mathrm{~Pb}$ for dating in a $75 \mathrm{~cm}$ core taken from the lagoon.

The within-class distributions of long-chain $\left(>\mathrm{C}_{20}\right)$ $n$-alkanes and $n$-alkanols are often used to infer terrestrial input into sediments. ${ }^{910}$ These compounds are abundant in plant epicuticular waxes, with a strong predominance of odd chain-lengths (mainly $\mathrm{C}_{29}$ and $\mathrm{C}_{31}$ ) for hydrocarbons and even chain-lengths (mainly $\mathrm{C}_{26}$ and $\mathrm{C}_{28}$ ) for alkanols. ${ }^{11}$ Marine algae and bacteria are minor sources, with carbon chain-lengths up to $\mathrm{C}_{22}{ }^{11-13}$ Apart from being of biogenic origin, saturated hydrocarbons can also be related to petroleum sources, but they show no clear odd/even predominance and a characteristic unresolved complex mixture. ${ }^{14,15}$

\section{Materials and Methods}

\section{Study area}

On Santa Catarina Island, where the capital city of Florianópolis is located, the main lagoons were formed by the entrapment of water bodies by sandy belts of reefs along the east coast. Conceição Lagoon is located at latitude $27^{\circ} 34^{\prime} \mathrm{S}$ and longitude $48^{\circ} 27^{\prime} \mathrm{W}$. It is the largest saltwater lagoon on the island, with a maximum depth of $9.0 \mathrm{~m}$ (average depth of $1.7 \mathrm{~m}$ ), total area of $19.2 \mathrm{~km}^{2}$ and water volume of $49 \times 10^{6} \mathrm{~m}^{3}$ (Figure 1). It is surrounded by mountains along the North, West and South margins with an extensive sandbank belt along the East margin, through which the lagoon is connected to the sea by a channel with an extension of $2 \mathrm{~km}, 20 \mathrm{~m}$ width and $2 \mathrm{~m}$ depth. Current direction through the channel to the South changes over the tidal cycle. Salinity is very low in the Southern area of the lagoon (oligohaline waters; 0.5 to $5.0 \%$ ) and increases in the central area $(6.5-32 \%$, average $18.5 \%$ ). Because of the influence of the João Gualberto River, the waters in the Northern region are also oligohaline (average $8.0 \%$ ). ${ }^{7}$

The first Portuguese immigrants from the Azores settled in small villages near the lagoon in the 18th century, but an intensified development occurred during the 19th century due to timber exploration, crops of manioc, sugar-cane and corn, and the uncontrolled urban occupation. Nowadays, despite the tourist activities, sewage treatment is insufficient to cope with the increasing population during the summer vacation and untreated wastes are discharged directly into the lagoon.

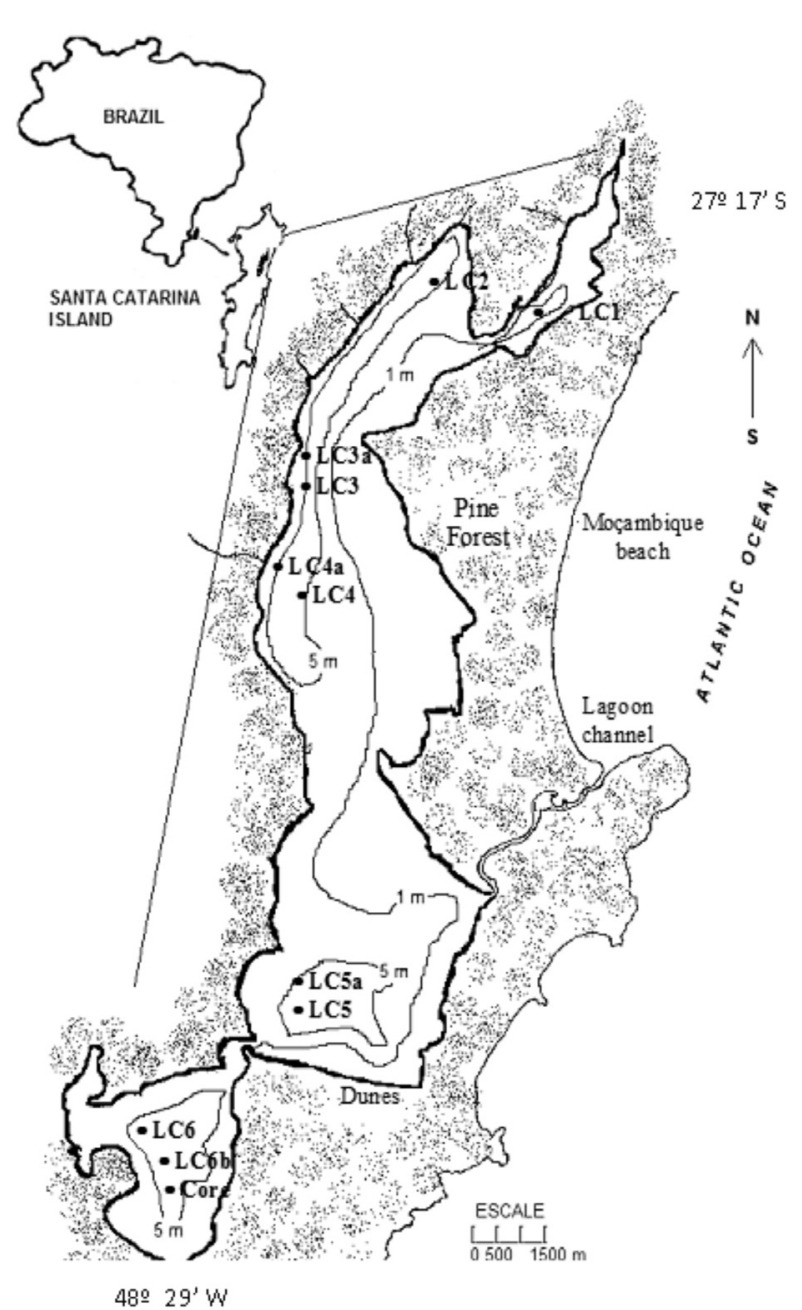

Figure 1. Sample locations of the surface sediment samples $(0-5 \mathrm{~cm})$ and the core $(75 \mathrm{~cm}$ depth) taken from Conceição Lagoon, Santa Catarina Island. Bathymetric contours in meters.

\section{Sampling and analysis}

Five sediment samples were collected using a van Veen grab sampler from the bottom ( $0-5 \mathrm{~cm}$ depth) of Conceição Lagoon in April 2001. The location of each surface sampling station is shown in Figure 1. These positions were chosen based on previous works, which evaluated chlorophyll in the water and the content of organic matter, nitrogen and grain size in the sediment. ${ }^{7}$ Divers using a $100 \mathrm{~cm} \times 7.5 \mathrm{~cm}$ diameter PVC tube collected one sediment core near station LC6. All surface samples were immediately immersed in $\mathrm{CH}_{2} \mathrm{Cl}_{2}(2 \mathrm{~mL})$, stored in previously-heated $\left(450{ }^{\circ} \mathrm{C}\right)$ glass jars, sealed with aluminum foil-lined lids and kept frozen until being freeze-dried in the laboratory. The core was capped in the field and stored frozen until being sectioned in the laboratory. The PVC tube was previously rinsed with $5 \%$ extran solution and distilled water $(3 x)$. 


\section{Bulk parameters}

The core was carefully subsectioned into $5 \mathrm{~cm}$ intervals and the subsamples stored frozen until chemical analysis. The samples were freeze-dried (Edwards F105) to constant weight; sediments were pulverized with a mortar and stored in glass jars. Dry sediment density and water content data were used to calculate the in situ dry sediment bulk density and porosity, to determine the uncompacted depth for each core section.

Immediately prior to lipid extraction, the storage solvent added to the surface sediments was evaporated and the sediment freeze-dried following the procedure described above for the sediment core. Aliquots from surface locations and all layers of the core were taken for elemental analysis. Subsamples $(0.1 \mathrm{~g})$ were transferred to small vials and previously decarbonated using $0.5 \mathrm{~mol} \mathrm{~L}^{-1} \mathrm{HCl}$ solution to determine total organic carbon (TOC) and nitrogen. TOC and N were measured using a Carlo Erba EA1110 CHNS-O analyzer after subsamples being centrifuged, washed with deionized water to eliminate excess of $\mathrm{HCl}$ and gently dried at $60{ }^{\circ} \mathrm{C}$.

\section{Particle size distribution}

Samples from all stations were taken for granulometric analysis following the procedure described by Suguio. ${ }^{16}$

\section{Phosphorus analysis}

For each station, two subsamples (with three replicates each) of $0.1 \mathrm{~g}$ of dried sediment each were used for the phosphorus analysis. One subsample was initially placed in a furnace for $1 \mathrm{~h}$ at $500{ }^{\circ} \mathrm{C}$. Both subsamples were then

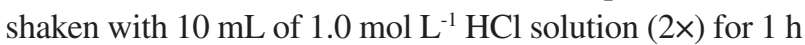
on a shaker. After centrifugation (6000 rpm, $10 \mathrm{~min})$, the liquid phase was placed in a Teflon ${ }^{\circledR}$ digester. Phosphorus extracted from the calcinated fraction is considered to be the total phosphorus (TP) and phosphorus extracted from the second treatment, with no calcination, the inorganic phosphorus (IP). Both fractions were digested for $4 \mathrm{~h}$ with $1.6 \mathrm{~mL}$ of potassium persulphate and $4.5 \mathrm{~mol} \mathrm{~L}^{-1}$ sulfuric acid solution at $80{ }^{\circ} \mathrm{C}$. The TP and IP fractions were determined as orthophosphate using the acidic molybdate-ascorbic acid method ${ }^{17}$ modified by Koroleff. ${ }^{18}$ Calibration curves ranging from 1.0 to $20.0 \mu \mathrm{mol} \mathrm{\textrm {L } ^ { - 1 }}$ were prepared using standard aqueous solution of orthophosphate. The organic fraction (OP) was obtained by subtracting the IP from TP. Procedural blanks did not reveal any contamination.

In order to evaluate the extraction efficiency of our method for phosphorus analysis (TP), a certified estuarine sediment sample (NIST, SRM1646a) was also analyzed. The result obtained for the recovery of total phosphorus $\left(\mathrm{TP}=267 \mu \mathrm{g} \mathrm{g}^{-1}\right.$ ), with an RSD value of $4.7 \%$ (triplicate analyses), was not significantly different from the certified TP value (270 $\mu \mathrm{g} \mathrm{g}^{-1} ; t$-Student's test, $\left.\mathrm{P}<0.05, n=5\right)$.

\section{Analytical procedure}

Lipids were extracted from the remaining freeze-dried samples for analysis. From each station, around $20 \mathrm{~g}$ of sediment were placed in glass tubes. The extractable lipids were obtained by successive extraction of the sediment with a mixture of $\mathrm{CH}_{2} \mathrm{Cl}_{2}: \mathrm{CH}_{3} \mathrm{OH}(2: 1, \mathrm{v} / \mathrm{v})$ and $\mathrm{CH}_{2} \mathrm{Cl}_{2}$, by ultra-sound for $20 \mathrm{~min}$ each. A solvent to sediment ratio of approximately 3:1 was used. Extracts were combined and rotary evaporated to just dryness. Lipids were then taken up in $2 \mathrm{~mL}$ of $\mathrm{CH}_{2} \mathrm{Cl}_{2}$ and passed through a Pasteur pipette micro column containing $1 \mathrm{~g}$ of combusted $\mathrm{Na}_{2} \mathrm{SO}_{4}$ to remove any residual water. ${ }^{19}$ Lipid isolations were performed in a glass column $(0.5 \mathrm{~cm}$ i.d. $\times 4 \mathrm{~cm}$ effective length) filled with previously activated alumina ( $2 \mathrm{~g}$, top part of the column) and silica ( $2 \mathrm{~g}$, lower part). ${ }^{20}$ The lipid extract was fractionated into three fractions using solvents of increasing polarity: F1 eluted with $18 \mathrm{~mL}$ hexane (hydrocarbons), F2 eluted with $20 \mathrm{~mL} \mathrm{CH}_{2} \mathrm{Cl}_{2}$ (no polycyclic aromatic hydrocarbons were detected in this fraction) and F3, containing the sterols and $n$-alkanols, eluted with $25 \%$ methanol in ethyl acetate. Each fraction was transferred to small vials $(2 \mathrm{~mL})$ and stored frozen at $-18{ }^{\circ} \mathrm{C}$ until analysis by gas chromatography (GC) and gas chromatography - mass spectrometry (GC-MS). Immediately before GC and GC-MS analyses, sterols and $n$-alkanols were converted to trimethylsilylether derivatives using bis(trimethylsilyl)-trifluoroacetamide (BSTFA). A known amount of $5 \alpha$-cholestane $\left(12.5 \mu \mathrm{g} \mathrm{g}^{-1}\right)$ was added to fractions F1 and F3 as an internal standard. Individual compounds were quantified from gas chromatographic peak areas by comparison with the area of the internal standard. Response factors were determined from quantitative mixtures of known compounds.

In order to verify the extraction efficiency, surrogate solutions containing deuterated alkanes $\left(\mathrm{C}_{20}, \mathrm{C}_{24}\right.$ and $\mathrm{C}_{30}$ ) were added to the surface subsamples and recovered together with the F1 fraction. Based on the recovery of the surrogates, the extraction efficiency was greater than $70 \%$.

GC analyses were carried out on a Shimadzu GC model 17A fitted with a split/splitless injector and a flame ionization detector. Temperatures: capillary injection port $300{ }^{\circ} \mathrm{C}$, detector $320^{\circ} \mathrm{C}$. Injection mode: manual $(1 \mu \mathrm{L})$ splitless (inlet purge on for $0.5 \mathrm{~min}$ ) with a split flow 
of 1:40. The column was a DB-1 capillary column of $30 \mathrm{~m} \times 0.25 \mathrm{~mm}$ i.d. and $0.25 \mu \mathrm{m}$ film thickness, with the following oven temperature program: $50-180{ }^{\circ} \mathrm{C}$ at $10{ }^{\circ} \mathrm{C} \min ^{-1}, 180-310{ }^{\circ} \mathrm{C}$ at $4{ }^{\circ} \mathrm{C} \min ^{-1}$, with a $15 \mathrm{~min}$ isotherm at $310^{\circ} \mathrm{C}$. $\mathrm{N}_{2}$ was used as the carrier gas.

Data acquisition and processing were performed on a Shimadzu CLASS-GC10 integrator. GC-MS analysis (EI mode, $70 \mathrm{eV}$; mass range 40-550 Daltons; $2.0 \mathrm{scan} \mathrm{s}^{-1}$ ) was carried out on a Shimadzu QP2000A MS interfaced to a Shimadzu GC model 14A. Conditions for the GC-MS analysis were as for GC except that $\mathrm{He}$ was used as the carrier gas. Identification of the compounds was based on comparing the gas chromatographic retention times of some peaks with those of authentic standards and by characteristic mass fragmentograms. Structural assignments were achieved by comparison with mass spectra of authentic standards and data published in the literature.

\section{Results and Discussion}

\section{Elemental composition at the sediment-water interface}

Bulk sediment parameters and molar ratios for all locations are listed in Table 1. TOC values showed no significant variation, with maximum content at station LC4 (3.81 $\left.\mathrm{mmol} \mathrm{g}^{-1}\right)$ and minimum content at station LC5 $\left(2.03 \mathrm{mmol} \mathrm{g}^{-1}\right)$. The range of TOC values is consistent with those previously reported for the same lagoon, ${ }^{7,8}$ and for other subtropical lagoons and estuaries.,21 Total phosphorus ranged from 2.89 to $10.00 \mu \mathrm{mol} \mathrm{g}{ }^{-1}$, and the highest values of TP and TOC were found at the same two stations (LC3 and LC4). The other three parameters analyzed (N, OP and IP), followed the same trend.
Interesting results were observed for the $\mathrm{P}$ fractions. Samples contained an average of $80 \%$ IP, ranging from $73 \%$ to $88 \%$. These values are higher than those found in the sediments of Ratones Mangrove (59 to 61\%), with no contribution of anthropogenic sources, but similar to those reported for the highly sewage contaminated sediments of Itacorubi Mangrove (79-87\%), both located on Santa Catarina Island..$^{22}$ From these results it is clear that the OP:IP ratio is affected by sources of phosphorus. According to Marins et al. ${ }^{23}$, IP accounts for the major fraction of total phosphorus in the estuary of the Jaguaribe River, in Ceará State, and comprises $60 \%$ of TP in sediments without anthropogenic input. However, the IP percentage can increase to $87 \%$ due to inputs from anthropogenic sources. Similar results have been reported for TP concentration in the sediments of the Tietê River, in the Pirapora Reservoir, in São Paulo State. ${ }^{23}$ As the average IP content found in the sediments of Conceição Lagoon is higher than $60 \%$ (from 73 to $88 \%$ ), it indicates the influence of non biogenic phosphorus on the IP:TP ratio.

The molar TOC/TP ratio ranged from 366 to 757 . Lower ratios were obtained for samples from locations LC3 and LC4 (Table 1). It is interesting to note that none of these sediment samples showed values close to the expected Redfield ratio of 106 for recent marine organic matter. ${ }^{24}$ The molar TOC/TP ratio seen in Conceição Lagoon sediments suggests a mix of terrestrial and marine organic matter inputs. The other two ratios shown in Table 1 also indicate mixed sources. It has been established that $\mathrm{C}: \mathrm{P}$ and $\mathrm{N}: \mathrm{P}$ values in freshwater generally tend to be higher than in the marine environment and, therefore, it is possible that the land-derived organic matter brought by river runoff to the sediments is responsible for both the

Table 1. Bulk sediment parameters and molar ratios at the sampling locations in Conceição Lagoon. Values shown are the average of three replicate analyses with RSD $<4.9 \%$

\begin{tabular}{|c|c|c|c|c|c|c|c|c|}
\hline Station & $\begin{array}{c}\mathrm{TOC}^{\mathrm{a}} / \\
\left(\mathrm{mmol} \mathrm{g}^{-1}\right)\end{array}$ & $\begin{array}{c}\mathrm{N} / \\
\left(\mathrm{mmol} \mathrm{g}^{-1}\right)\end{array}$ & $\begin{array}{c}\mathrm{TP}^{\mathrm{b}} / \\
\left(\mu \mathrm{mol} \mathrm{g} \mathrm{g}^{-1}\right)\end{array}$ & $\begin{array}{c}\text { OP / } \\
\left.(\mu \mathrm{mol} \mathrm{g})^{-1}\right)\end{array}$ & $\begin{array}{c}\mathrm{IP} / \\
\left(\mu \mathrm{mol} \mathrm{g}{ }^{-1}\right)\end{array}$ & $\begin{array}{c}\text { TOC/TP / } \\
\text { (molar) }\end{array}$ & $\begin{array}{c}\mathrm{TOC} / \mathrm{N} / \\
\text { (molar) }\end{array}$ & $\begin{array}{l}\mathrm{N} / \mathrm{TP} / \\
\text { (molar) }\end{array}$ \\
\hline LC1 & 2.20 & 0.17 & 2.89 & 0.86 & 2.20 & 757 & 11.9 & 63 \\
\hline LC2 & 2.27 & 0.18 & - & - & - & - & 12.6 & - \\
\hline LC3 & 3.66 & 0.36 & 10.00 & 1.43 & 8.80 & 366 & 10.2 & 36 \\
\hline $\mathrm{LC} 3 \mathrm{a}^{\mathrm{c}}$ & 3.58 & 0.33 & - & - & - & - & 10.5 & - \\
\hline LC4 & 3.81 & 0.35 & 8.80 & 1.60 & 7.22 & 433 & 10.9 & 40 \\
\hline $\mathrm{LC} 4 \mathrm{a}^{\mathrm{c}}$ & 5.00 & 0.70 & - & - & - & - & 7.1 & - \\
\hline LC5 & 2.03 & 0.22 & 3.30 & 0.84 & 2.44 & 619 & 9.2 & 67 \\
\hline $\mathrm{LC} 5 \mathrm{a}^{\mathrm{c}}$ & 2.10 & 0.24 & 3.32 & - & - & - & 8,6 & - \\
\hline LC6 & 2.25 & 0.18 & 5.52 & 0.89 & 4.63 & 444 & 12.4 & 33 \\
\hline $\mathrm{LC6}^{\mathrm{c}}$ & 2.21 & 0. & 5.38 & - & - & - & - & - \\
\hline
\end{tabular}

${ }^{\mathrm{a}}$ TOC: total organic carbon; ${ }^{\mathrm{b}}$ Phosphorus: Total (TP), inorganic (IP) and organic (OP); ${ }^{\mathrm{c}}$ Previous work. ${ }^{8}$ 
high average TOC/TP (366-757) and N/TP (33-67) molar values in the sediments analyzed. ${ }^{25}$ Another possibility is an increase in TOC/TP and N/TP ratios in sediments due to a higher productivity in the water column, in response to an increased anthropogenic input of nitrate and phosphate. ${ }^{26}$ From the TOC/N ratios in Table 1 (9.2-12.6), the influence of terrestrial organic matter on this ratio can be noted. Generally, values lower than 10 indicate a predominance of marine organic matter influx.

The particle size distribution in Conceição Lagoon sediments revealed that the sample from station LC2 has the highest sand content (87\%), which drops to less than $40 \%$ for samples from stations LC3 and LC4 (Figure 2a). In contrast, silt is the dominant sedimentary component at these stations, showing good correlation with TOC. High percentages of fine particles are commonly found along with high TOC levels, ${ }^{27,28}$ which suggest that these may be areas of major accumulation of terrigenous detritus,
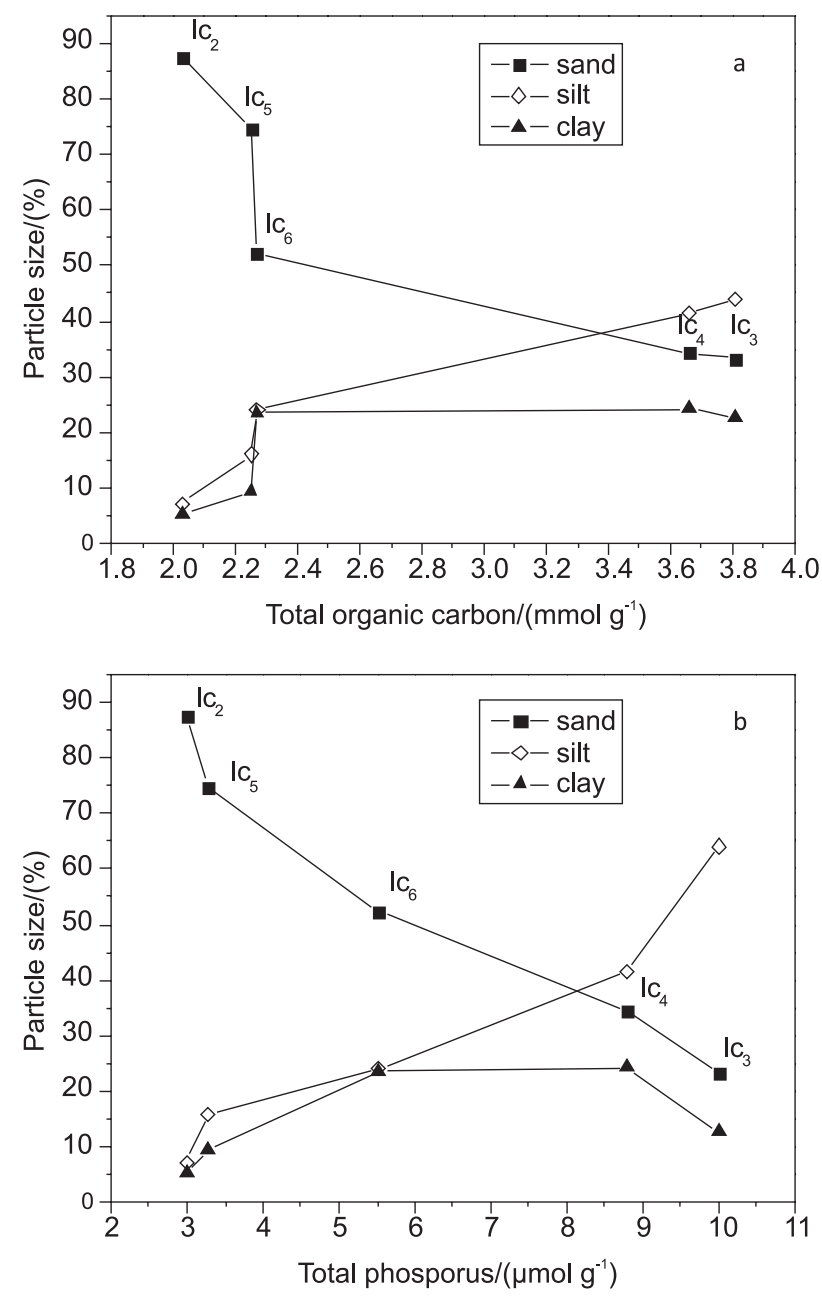

Figure 2. Correlation between particle size $(\%)$ and total organic carbon - TOC (a) and total phosphorus - TP (b) in surface sediments of Conceição Lagoon. possibly brought by the Cachoeira River. As for TOC, the increase in TP content was also associated with a decrease in the sand and increase in the silt percentage (Figure 2b).

\section{Lipid compounds}

Here we will discuss data on $n$-alkane, $n$-alkanol and sterol concentrations and the distribution patterns of individual compounds in the surface sediments of Conceição Lagoon (Table 2). For all samples, the distribution of total $n$-alkanols $\left(\mathrm{C}_{14}-\mathrm{C}_{30}\right)$ showed a predominance of compounds with even carbon numbers, mainly those extending from $\mathrm{C}_{24}$ to $\mathrm{C}_{28}$ and exhibited bimodal distribution with a maximum at $\mathrm{C}_{18}$ and $\mathrm{C}_{28}$. Concentrations were highest at station LC3 (amounting to $1.2 \mu \mathrm{g} \mathrm{g}^{-1} \mathrm{dry}$ sediment) and the lowest values were found at station LC5 $\left(0.2 \mu \mathrm{g} \mathrm{g}^{-1}\right)$. With respect to total $n$-alkanes $\left(\mathrm{C}_{20}-\mathrm{C}_{36}\right)$, samples showed an odd carbon number predominance with major contributions ranging from $\mathrm{C}_{25}$ to $\mathrm{C}_{33}$. The highest concentrations were also detected at station LC3 (5.0 $\mu \mathrm{g} \mathrm{g}^{-1}$ dry sediment) and the lowest values at station LC5 ( $0.4 \mu \mathrm{g} \mathrm{g}^{-1}$ dry sediment), which was nearly 10 times lower than that of station LC3. As reported by other authors, ${ }^{29-31}$ the distribution of $n$-alkanols and $n$-alkanes seen in Conceição Lagoon sediments is commonly attributed to land plant inputs.

In fact, the results mentioned above were confirmed by the use of ratios based on the distribution of $n$-alkanols and $n$-alkanes in the surface sediment samples. The Carbon Preference Index (CPI) was calculated in the range of $\mathrm{C}_{22}-\mathrm{C}_{32}$ for $n$-alkanols and $\mathrm{C}_{23}-\mathrm{C}_{31}$ for $n$-alkanes and the results show that values were higher than two for both indexes, indicating a large contribution from terrigenous particulate material (Table 2). Another ratio indicative of source dominance is the terrigenous/aquatic ratio (TAR), which is based on the relative abundance of the long-chain over the short-chain compounds ( $n$-alkanols and $n$-alkanes). All the values calculated were greater than two, showing the importance of the terrigenous compounds. The $\mathrm{TAR}_{\mathrm{ALK}}$ values were higher than those for $\mathrm{TAR}_{\mathrm{OH}}$ which may indicate preferential degradation of aquatic $n$-alkanols relative to aquatic $n$-alkanes or that the sources of these terrigenous compounds contain a higher proportion of $n$-alkanes than $n$-alkanols. ${ }^{32}$ However, station LC6 showed distinct ratios, with $\mathrm{TAR}_{\mathrm{OH}}(6.0)$ being greater than $\mathrm{TAR}_{\mathrm{ALK}}(5.0)$. The results for both TAR ratios suggest a dominant allochthonous input of extractable lipid compounds.

All sterols detected in the surface samples are described below. Their identifications were based on their mass spectra, relative retention times, comparison with authentic 
Table 2. Concentrations (in $\mu \mathrm{g} \mathrm{g}^{-1}$ ) of total $n$-alkanols from $\mathrm{C}_{14}$ to $\mathrm{C}_{31}$ and $n$-alkanes from $\mathrm{C}_{15}$ to $\mathrm{C}_{32}$ in surface sediments of Conceição Lagoon; CPI: Carbon Preference Index; TAR: Terrestrial Aquatic Ratio; percentage of sterols $\left(\mathrm{C}_{27}-\mathrm{C}_{29}\right)$ and stanol/stenol ratios. Values shown are the average of duplicate analyses

\begin{tabular}{|c|c|c|c|c|c|c|c|c|c|c|c|c|}
\hline \multirow{3}{*}{ Station } & \multirow{3}{*}{$\begin{array}{c}\text { Total } \\
n \text {-alkanols }\end{array}$} & \multirow{3}{*}{$\begin{array}{c}\text { Total } \\
n \text {-alkanes }\end{array}$} & \multirow{3}{*}{$\mathrm{CPI}_{\mathrm{OH}}{ }^{a}$} & \multirow{3}{*}{$\mathrm{CPI}_{\mathrm{ALK}}{ }^{\mathrm{b}}$} & \multirow{3}{*}{$\mathrm{TAR}_{\mathrm{OH}}{ }^{\mathrm{c}}$} & \multirow{3}{*}{$\mathrm{TAR}_{\mathrm{ALK}}{ }^{\mathrm{d}}$} & \multicolumn{6}{|c|}{ Sterols and stanol/stenol } \\
\hline & & & & & & & \multicolumn{3}{|c|}{$(\%)$} & \multicolumn{3}{|c|}{$\Delta^{0} / \Delta^{5}$} \\
\hline & & & & & & & $\mathrm{C}_{27}$ & $\mathrm{C}_{28}$ & $\mathrm{C}_{29}$ & $\mathrm{C}_{27}$ & $\mathrm{C}_{28}$ & $\mathrm{C}_{29}$ \\
\hline LC2 & 0.9 & 3.0 & 2.8 & 2.6 & 2.3 & 7.4 & 40 & 32 & 28 & 0.89 & 0.90 & 0.78 \\
\hline LC3 & 1.2 & 5.0 & 4.7 & 4.0 & 3.5 & 9.6 & 43 & 30 & 27 & 0.81 & 0.78 & 0.79 \\
\hline LC4 & 0.7 & 2.1 & 3.5 & 2.2 & 2.6 & 5.3 & 41 & 33 & 26 & 0.77 & 0.68 & 0.81 \\
\hline LC5 & 0.2 & 0.4 & 3.3 & 4.0 & 2.6 & 7.6 & 39 & 32 & 29 & 0.87 & 0.81 & 0.69 \\
\hline LC6 & 0.3 & 0.6 & 4.8 & 2.4 & 6.0 & 5.0 & 43 & 26 & 31 & 0.81 & 0.73 & 0.84 \\
\hline
\end{tabular}

${ }^{a} \mathrm{CPI}$ calculated in the $\mathrm{C}_{22}-\mathrm{C}_{32} n$-alkanol range; ${ }^{\mathrm{b}} \mathrm{CPI}$ calculated in the $\mathrm{C}_{23}-\mathrm{C}_{31} n$-alkane range; ${ }^{\mathrm{c}}$ TAR calculated for $n$-alkanols $\left(\mathrm{C}_{24}+\mathrm{C}_{26}+\mathrm{C}_{28}\right) /\left(\mathrm{C}_{14}+\mathrm{C}_{16}+\right.$ $\left.\mathrm{C}_{18}\right) ;{ }^{\mathrm{d}}$ TAR calculated for $n$-alkanes $\left(\mathrm{C}_{27}+\mathrm{C}_{29}+\mathrm{C}_{31}\right) /\left(\mathrm{C}_{15}+\mathrm{C}_{17}+\mathrm{C}_{19}\right)$.

standards and key fragment ions of TMS derivatives: $m / z, 129$ for $\mathrm{C}_{27}-\mathrm{C}_{29} \Delta^{5}$ and $\Delta^{5,22}$ components; 251 for $\mathrm{C}_{27}-\mathrm{C}_{29} \Delta^{0}$ and 257 for $\mathrm{C}_{27}-\mathrm{C}_{29} \Delta^{22}$. Sterols are composed mainly of $\mathrm{C}_{27}$ components $(5 \beta$-cholestan- $3 \beta$-ol, cholesta-5,22dien- $3 \beta$-ol, cholest-5-en-3 $\beta$-ol and $5 \alpha$-cholestan-3 $\beta$-ol), which account for $39-43 \%$ of the total sterols, and are usually associated with microbes or other marine sources, since they are not commonly found in higher plant waxes. ${ }^{9}$ Cholest-5-en-3 $\beta$-ol $\left(\mathrm{C}_{27} \Delta^{5}\right)$ is the major component of $\mathrm{C}_{27}$ sterols in all the surface samples. Compounds that are generally employed as fecal pollution indicators were identified: $5 \beta$-cholestan-3 $\beta$-ol (coprostanol) and $5 \alpha$-cholestan-3 $\beta$-ol. However, using the ratio $(5 \beta / 5 \beta+5 \alpha)$ stanol proposed by Grimalt et al..$^{33}$, we found values ranging from 0.17 to 0.20 , which are not considered to be indicative of significant sewage contamination.

The abundance of $\mathrm{C}_{28}$ and $\mathrm{C}_{29}$ sterols detected are close to the $\mathrm{C}_{27}$ components (Table 2). On average, they account for 30 and $28 \%$ of the total sterols, respectively. 24-Methylcholesta-5,22-dien-3 $\beta$-ol $\left(\mathrm{C}_{28} \Delta^{5,22}\right)$ and 24-ethylcholest-5-en-3 $\beta$-ol $\left(\mathrm{C}_{29} \Delta^{5}\right)$ are the major components. These two groups of sterols come mainly from higher plants. ${ }^{11}$ However, in sediments dominated by terrestrial sterols, 24 -ethylcholest-5-en-3 3 -ol is usually detected as the major component.

As cholest-5-en-3 $\beta$-ol $\left(\mathrm{C}_{27} \Delta^{5}\right)$ and 24-ethylcholest-5-en$3 \beta$-ol $\left(\mathrm{C}_{29} \Delta^{5}\right)$ have been shown to relate to autochthonous and allochthonous material, respectively, we used the ratio $\mathrm{C}_{27} \Delta^{5} / \mathrm{C}_{29} \Delta^{5}$ for comparison with data reported by other authors. ${ }^{34,35}$ Values of this ratio ranged from 1.21 to 1.30 in the surface sediments of Conceição Lagoon. Considering the possible sewage origin of cholesterol, the high ratio values encountered at these stations suggest that there is more than one source of cholesterol. Besides domestic discharges, the sources of the inputs may vary with time and include plankton production and bioaccumulation. ${ }^{35}$
Another interesting issue regarding sterols is the possible changes that occur in the sterol skeletons. These changes have been used to assess microbially-mediated diagenetic transformation reactions. Two reactions are commonly employed, the reduction of cholest-5-en-3 3 -ol

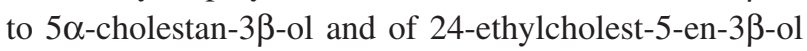
to 24 -ethyl- $5 \alpha$-cholestan-3 $\beta$-ol. ${ }^{36,37}$ However, stanols in sediments can originate from direct biogenetic inputs and possible mixtures of $5 \alpha$-stanols from marine organisms cannot be ruled out. Previous data have shown that the stanol/stenol ratios are only 0.1-0.2 in plankton ${ }^{32,38}$ and leaf waxes. ${ }^{9}$ Ratios for the three sterol pairs were calculated: $5 \alpha$-cholestan- $3 \beta$-ol/cholest-5-en- $3 \beta$-ol $\left(\mathrm{C}_{27} \Delta^{\%} / \mathrm{C}_{27} \Delta^{5}\right)$, 24 -methylcholest-5-en-3 $\beta$-ol/24-methyl-5 $\alpha$-cholestan-

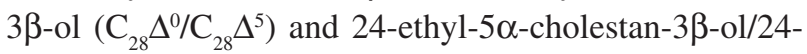
ethylcholest-5-en-3 $\beta$-ol $\left(\mathrm{C}_{29} \Delta^{0} / \mathrm{C}_{29} \Delta^{5}\right)$ (Table 2). Values for these ratios averaged 0.80 and are very high compared to other studies in which the average values for stanol/stenol pairs are below $0.60 . .^{35,39}$ One possible reason for the higher ratios is a direct input of $5 \alpha(\mathrm{H})$-stanols from diatoms as they are likely to be found in Conceição Lagoon. ${ }^{8}$ Duan et al..$^{32}$ also reported high values (>0.91) for stanol/ stenol ratios in sediments from marsh deposits.

\section{Particle size and elemental composition with depth profile}

The core interval from 0 to $50 \mathrm{~cm}$ is dominated by silt and clay, averaging close to $70 \%$ (Figure 3a). However, below $50 \mathrm{~cm}$ the relative percentage of sand showed a strong increase. The maximum value occurs at a depth of $60-65 \mathrm{~cm}$, amounting to $80 \%$. These variations appear to be associated with events which occurred in the $19^{\text {th }}$ century. The first immigrants from the Azores used to grow their crops around the lagoon and it was a common practice to burn the primary vegetation to clear the land. 
Thus, between plantation periods the soil might have been exposed to erosion, and high levels of sand may have been transported to the bottom of the lagoon. This
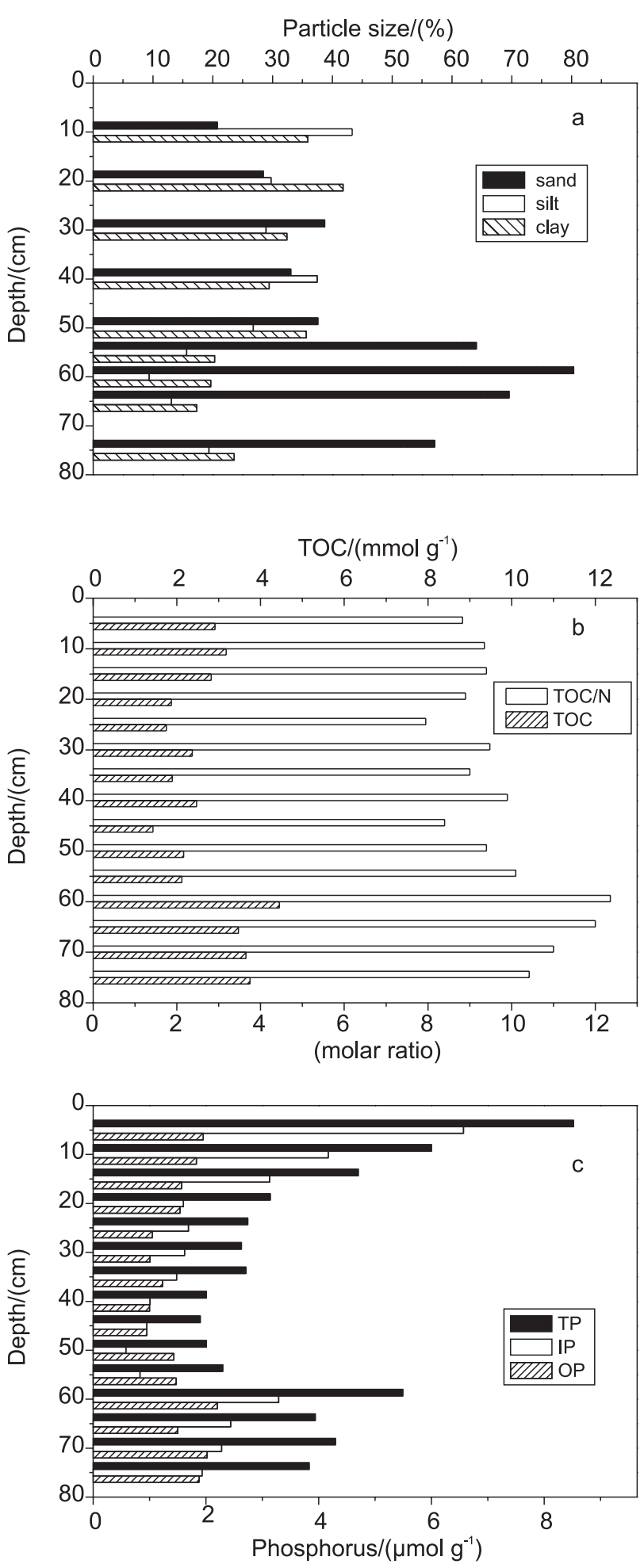

Figure 3. Histograms with the depth profiles of the particle size composition (a), TOC and molar TOC/N ratio (b), and phosphorus (total - TP, inorganic - IP, and organic - OP) (c) in the sediment core taken from Conceição Lagoon (core LC3). agricultural practice had ended by the beginning of the last century. The results seen here for particle size changes with depth are in agreement with the chronology obtained through the ${ }^{210} \mathrm{~Pb}$ (Figure 4e) determination. Variations in the TOC concentration with depth were observed in the deeper sediments, with maximum concentration at a depth of $60-65 \mathrm{~cm}\left(4.5 \mathrm{mmol} \mathrm{g}^{-1}\right.$; Figure $\left.3 \mathrm{~b}\right)$. Nitrogen did not vary considerably with depth and ranged from 0.17 to $0.33 \mathrm{mmol}^{-1}$. However, the TOC/N ratio varied more significantly through the profile. The upper sediment $(5-55 \mathrm{~cm})$ values ranged from 8 to 10 , while in the deeper sediments they increased to around 11.5 , with the highest value of 12.4 at a depth of $60-65 \mathrm{~cm}$.

The TP values showed large variations with the depth (Figure 3c) and were consistent with the changes in TOC, $\mathrm{TOC} / \mathrm{N}$ and particle size composition. Values ranged from 8.52 to $1.90 \mu \mathrm{mol} \mathrm{g} \mathrm{g}^{-1}$ (at depths of 5-10 and $45-50 \mathrm{~cm}$, respectively). In the deeper sediments (below $55 \mathrm{~cm}$ ) TP increased again and had a profile similar to TOC. The IP fraction had the same profile as TP, with the maximum $\left(6.5 \mu \mathrm{mol} \mathrm{\textrm {g } ^ { - 1 }}\right)$ value found in the upper sediment $(5-10 \mathrm{~cm})$, dropping to near $0.58 \mu \mathrm{mol} \mathrm{g}{ }^{-1}$ at $50-55 \mathrm{~cm}$. In contrast, it was observed that OP remained almost constant, with values raging from $0.95(45-50 \mathrm{~cm})$ to $2.02 \mu \mathrm{mol} \mathrm{g} \mathrm{g}^{-1}$ $(60-65 \mathrm{~cm})$. Only at the depth intervals of $50-55$ and $55-60 \mathrm{~cm}$ were OP concentrations higher than those of IP.

From the results obtained for particle size in the core, it would be expected that below a depth of $50 \mathrm{~cm}$ concentrations of organic carbon, nitrogen and phosphorus would decrease, given the predominance of sand particles (over 60\%). However, the bulk organic matter was very high below $50 \mathrm{~cm}$, showing that in the past an important source of organic matter associated with a high influx of sand formed the bottom sediments of Conceição Lagoon.

\section{Hydrocarbon variations with depth profile}

In order to investigate possible changes in the sources of organic matter through the core, we plotted the vertical profile of three saturated hydrocarbons (Figure 4b), representing typical land-derived sources ${ }^{40}$ and compared it with the TOC profile (Figure 4a). The relative distributions of $\mathrm{C}_{27}, \mathrm{C}_{29}$ and $\mathrm{C}_{31}$ were very similar to that of TOC through the core, suggesting the same source for all three compounds. However, a strong increase in $\mathrm{C}_{29}$ and $\mathrm{C}_{31}$ concentrations (over $100 \mathrm{ng} \mathrm{g}^{-1}$ ) was observed below $50 \mathrm{~cm}$, with values approximately 2- to 3 -fold higher than the average concentration above this depth. To further investigate these results, we employed the CPI index and ratios of long to short $n$-alkane chains, to assess relative changes in the contribution of allochthonous $v s$. 

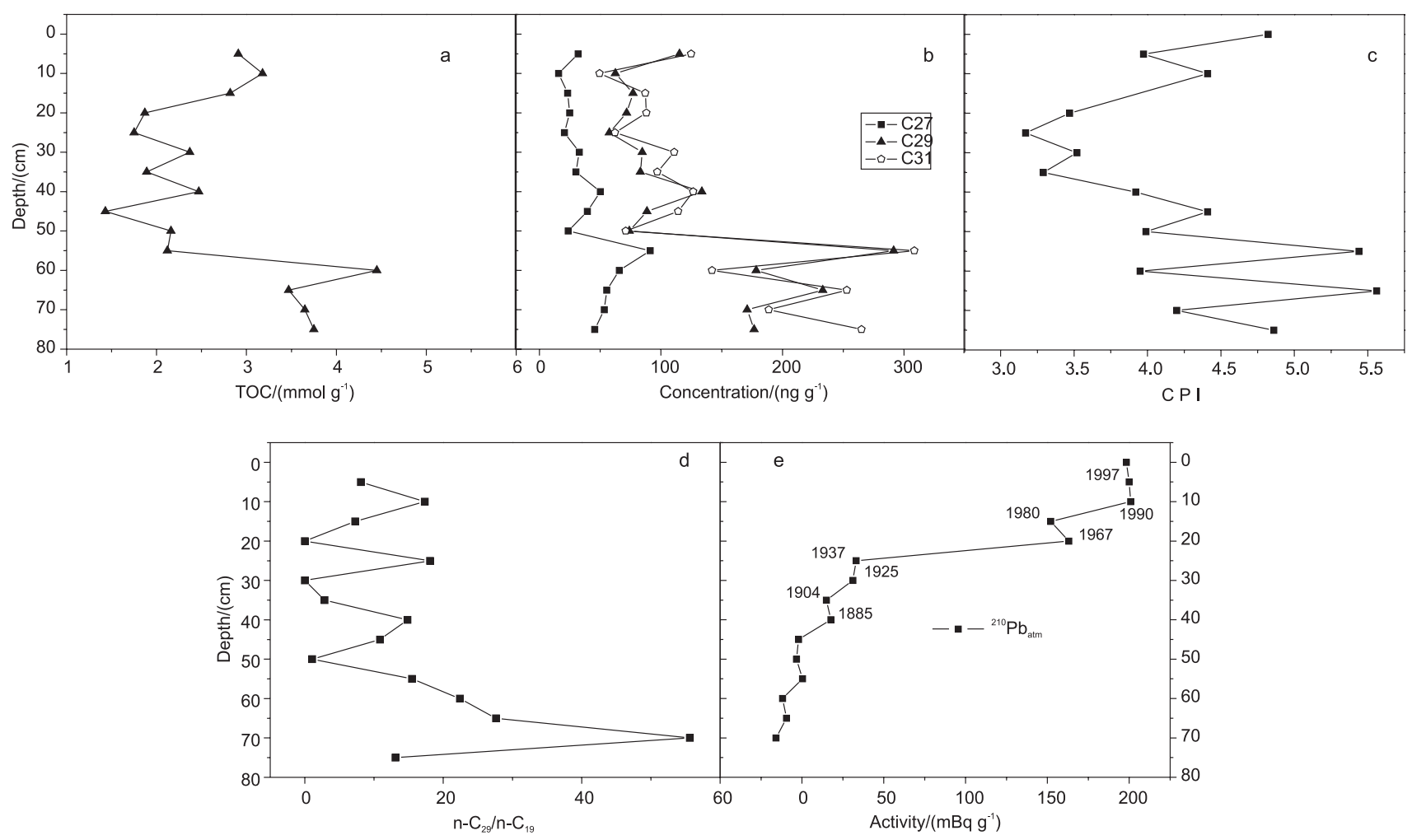

Figure 4. Depth profiles of: (a) total organic carbon (TOC) and molar TOC/N ratio, (b) linear $n$-alkanes $\left(\mathrm{C}_{27}, \mathrm{C}_{29}\right.$ and $\left.\mathrm{C}_{31}\right)$, (c) Carbon Preference Index (CPI), (d) Terrestrial Aquatic Ratio (TAR) and (e) the excess ${ }^{210} \mathrm{~Pb}$ with chronology for core near the LC6 station.

autochthonous components. ${ }^{2,41}$ The CPI in the range of $\mathrm{C}_{23}-\mathrm{C}_{31}$ showed considerable variation with depth, with a value of 4.8 in the surface sediment and a decrease with depth to $3.1-3.3$ at $30-40 \mathrm{~cm}$. The CPI increases again in the deeper sediments where higher ratios were observed (Figure 4c), in agreement with the TOC variation (Figure 4a). Such variation with depth may be associated with distinct sources of these long-chain $n$-alkanes. It is also possible that due to the different sources and events in the past, these hydrocarbons show different extents of degradation. According to Gagozian and Peltzer ${ }^{42}$ hydrocarbons associated with sources of refractory organic material become less susceptible to biodegradation and result in variations of CPI with depth. The $\mathrm{C}_{29} / \mathrm{C}_{19}$ ratio also varies considerably with depth and shows a strong increase below $50 \mathrm{~cm}$, consistent with the TOC profile (Figure 4d). Changes in the relative proportions of long to short $n$-alkane chains are probably caused by an enhanced contribution of terrigenous biomass.

\section{Mixing processes with depth}

The radionuclide ${ }^{210} \mathrm{~Pb}$ has been widely used to monitor the role of benthic or infaunal organisms in mixing sediments, which is an important near-surface process in all oxic sediments. ${ }^{43}$ The importance of ${ }^{210} \mathrm{~Pb}$ $\left(\mathrm{t}_{1 / 2}=22.3\right.$ years $)$ as a mixing tracer is based on the fact that its activity falls exponentially in the first few centimeters of sediment and its relevance to mixing on a 100-year time scale. ${ }^{44,45}$ The transport of ${ }^{210} \mathrm{~Pb}$ and other radionuclides (e.g. ${ }^{234} \mathrm{Th},{ }^{228} \mathrm{Th},{ }^{239,240} \mathrm{Pu}$ ) to the bottom of a water body appear to be primarily associated with the falling biogenic particles. Hence, the use of ${ }^{210} \mathrm{~Pb}$ to evaluate the effect of sediment mixing on lipid compounds also transported to the sediment by biogenic particles is significant.

The depth profile of ${ }^{210} \mathrm{~Pb}_{\text {atm }}$ activity (Figure $4 \mathrm{e}$ ) from $0-40 \mathrm{~cm}$ shows close similarities with those of TOC and $n$-alkane concentration. The relatively high abundance of ${ }^{210} \mathrm{~Pb}_{\text {atm }}\left(150-200 \mathrm{mBq} \mathrm{g}^{-1}\right)$ in the first $20 \mathrm{~cm}$ of the core is consistent with the higher TOC values. Similarly to the TOC, ${ }^{210} \mathrm{~Pb}_{\text {atm }}$ abruptly decreased at a depth of $10-20 \mathrm{~cm}$ (Figure 4e). However, this steep decrease is not observed for terrigenous hydrocarbons (Figure $4 b$ ). These results appear to imply that the trend in the variation of the excess activity of particle-associated radionuclides with depth, in this case ${ }^{210} \mathrm{~Pb}_{\text {atm }}$, resembles that of the bulk TOC rather than land-derived compounds. 


\section{Conclusions}

The fine particle size (silt and clay) and elemental compositions show good correlation in the five surface samples at the Conceição lagoon. The lipid compositions of these samples have characteristic features of terrigenous and aquatic inputs, with no clear sign of hydrocarbons derived from anthropogenic contamination. $n$-Alkanols and $n$-alkanes in the surface samples are dominated by long-chain homologues with a maximum of $\mathrm{C}_{26}$ and $\mathrm{C}_{31}$, respectively, which are commonly assigned to land plants.

The sediment core shows that despite good correlations of fine particle content with variations of TP, TOC/N and long-chain hydrocarbons within the top $50 \mathrm{~cm}$, below this depth the sediment becomes enriched in sand and the other parameters also increase. These increases coincide with the period of agricultural burn-off in the region, which increases erosion and the influx of terrestrial material.

\section{Acknowledgments}

Thanks are due to the Rescue \& Save Brigade of Florianópolis City for helping us to collect samples at the Conceição Lagoon. Dr Antônio Mozeto and his group for the ${ }^{210} \mathrm{~Pb}$ analysis. Scholarships for C. A. Silva and C. R. Oliveira were provided by CAPES. Financial support was provided by Petrobras.

\section{References}

1. Meyers, P. A.; Ishiwatari, R.; In Organic Geochemistry, Principles and Applications; Engel, M. H.; Macko, S. A.; eds.; Plenum Press: New York, 1993, p. 185.

2. Muri, G.; Wakeham, S. G.; Pease, T.; Faganeli, J.; Org. Geochem. 2004, 35, 1083. Rodrigues Neto, R.; Madureira, L. A. S.; Acta Limnol. Bras. 2000, 12, 113.

3. Canuel, E. A.; Martens, S. C.; Deep Sea Res. 1993, 36, 121.

4. Hernandez, M. E.; Mead, R.; Peralba, M. C.; Jaffé, R.; Org. Geochem. 2001, 32, 21.

5. Xu, S.; Gao, X.; Liu, M.; Chen, Z.; Geomorphology 2001, 41, 207.

6. Ruiz-Fernandéz, A. C.; Hillaire-Marcel, C.; Ghaleb, B.; SotoJiménez, M.; Paez-Osuna, F.; Environ. Pollut. 2002, 118, 365.

7. Fonseca, A.; Biotemas 2006, 19, 7. Torronteguy, M. C.; Dissertation, Universidade Federal de Santa Catarina, Florianópolis, Brazil, 2002; Klingebiel, A.; Sierrra de Ledo, B.; Aquitaine Ocean 1997, 3, 129; Odebrecht, C.; Gomas Jr., F. C. In Hidrografia e Matéria Particulada em Suspensão na Lagoa da Conceição, Ilha de Santa Catarina, SC. O Ecossistema da
Lagoa da Conceição. Ledo, B. S.; Soriano-Sierra, L., eds., FEPEMA: Florianópolis, Brazil, 1999, 423.

8. Bresciani, L. F. V.; MSc Dissertation, Universidade Federal de Santa Catarina, Brazil, 1998. Santiago, A. G.; Bianchi, M. F.; Feitosa, F. F.; Rosa, M. M.; http://www.dpi.inpe.br/ flavia/ pessoal/files/Santiago paisagem.pdf, accessed in August 2007.

9. Rieley, G.; Collier, R. J.; Jones, D. M.; Eglinton, G.; Org. Geochem. 1991, 17, 901.

10. Madureira, L. A. S.; van Kreveld, S. A. V.; Eglinton, G.; Conte, M. H.; Ganssen, G.; Hinte, J. E.; Ottens, J.; Paleoceanography 1997, 12, 255; Jeng, Woei-Lih.; Mar. Chem. 2006, 102, 242.

11. Volkman, J. K.; Barret, S. M.; Blackburn, S. I.; Mansour, M. P.; Sikes, E. L.; Gelin, F.; Org. Geochem. 1998, 29, 1163.

12. Volkman, J. K.; Eglinton, G.; Corner, E. D. S.; Phytochemistry 1980, 19, 1809

13. Saliot, A. In Marine Organic Geochemistry; Duursma, E.; Dawson, R.; eds.; Elsevier: Amsterdam, 1981, p. 237.

14. Readman, J. W.; Fillmann, G.; Tolosa, I.; Bartocci, J.; Villeneuve, J.-P.; Catinni, C.; Mee, L. D.; Mar. Pollut. Bull. 2002, 44, 48.

15. Medeiros. P. M.; Bicego, M. C.; Castelão, R.M.; Del Rosso, C.; Fillmann, G.; Zamboni, A. J.; Environ. Int. 2005, 31, 77.

16. Suguio, K.; Introdução à Sedimentologia, Universidade de São Paulo: São Paulo, Brazil, 1973.

17. Murphy, I.; Riley, S. P.; Analyt. Chim. Acta 1962, 27, 223.

18. Koroleff, F. In Methods of Seawater Analysis; Grasshoff, K.; Ehrhardt, M.; Kremling, K., eds., $2^{\text {nd }}$ ed., Verlag Chemie: Weinheim, 1983, 125.

19. Madureira,L.A. S.; Eglinton, G.; Conte, M.H.; Paleoceanography 1995, 10, 627.

20. Wang, Z.; Fingas, M.; Li, K.; J. Chromatogr. Sci. 1994, 32, 361.

21. Jeng, W. L.; Huh, C. A.; Org. Geochem. 2004, 35, 647.

22. Mater, L.; Alexandre, M. R.; Hansel, F. A.; Madureira, L. A. S.; J. Braz. Chem. Soc. 2004, 15, 725.

23. Marins, R. V.; Paula Filho, F. J.; Rocha, C. A. S.; Quim. Nova 2007, 30, 1208; Silva, I. S.; Toledo, M. C. M.; Geochim. Brasil. 1997, 11, 243.

24. Takahashi, T.; Broecker, W. S.; Langer, S.; J. Geophys. Res. 1985, 90, 6907.

25. Bouillon, S.; Dahdouh-Guebas, F.; Rao, A. V. V. S.; Koedam, N.; Dehairs, F.; Hydrobiologia 2003, 495, 33.

26. Emeis, K. C.; Struck, U.; leipe, T.; Pollehme, F.; Kunzendorf, H.; Christiansen, C.; Mar. Geol. 2000, 167, 43.

27. Muniz, P.; Danulat, E.; Yannicelli, B.; Garcia-Alonso, J.; Medina, G.; Bícego, M. C.; Environ. Int. 2003, 1096, 1.

28. Nishigima, F. N.; Weber, R. R.; Bícego, M. C.; Mar. Pollut. Bull. 2001, 42,1064.

29. Gomes, A. O.; Azevedo, D. A.; J. Braz. Chem. Soc. 2003, 14, 358. 
30. Azevedo, D. A.; J. Braz. Chem. Soc. 2003, 14, 97.

31. Eglinton, G.; Hamilton, R. J.; Science 1967, 156, 1322.

32. Duan, Y.; Ma, Lanhua.; Org. Geochem. 2001, 32, 1429.

33. Grimalt, J. O.; Fernández, P.; Bayona, J. M.; Albaigés, J.; Environ. Sci. Technol. 1990, 24, 357.

34. Huang, W-Y.; Meinschein, W. G.; Geochim. Cosmochim. Acta 1976, 40, 323.

35. Sicre, M-A.; Tian, R. C.; Broyelle, I.; Saliot, A.; Mar. Chem. 1993, 42, 11.

36. Gaskell, S. J.; Eglinton, G.; Nature 1975, 254, 209.

37. Nishinura, M.; Koyama, T.; Geochim. Cosmochim. Acta 1977, 41,379 .

38. Wakeham, S.; Canuel, E.; Org. Geochem. 1990, 20, 563.

39. Fernandes, M. B.; Sicre, M- A.; Cardoso, J. N.; Macedo, S. J.; Sci. Total Environ. 1999, 23, 1.
40. Bourbonniere, R. A.; Meyers, P. A.; Limnol. Ocean. 1996, 41, 352.

41. Meyers, P. A.; Chem. Geol. 1994, 144, 289.

42. Gagosian, R. B.; Peltzer, E. T.; Org. Geochem. 1986, 10, 661. 43. Smith, D. J. Eglinton, G.; Morris, R. J.; Nature 1983, 304, 259.

44. Cochran, J. K.; Geochim. Cosmochim. Acta 1985, 49, 1195.

45. Thomson, J.; Colley, S.; Weaver, P. P. E.; Earth Planet. Sci. Lett. 1988, 90, 157.
Received: October 4, 2007

Web Release Date: September 24, 2008 